\title{
Posterior Respiratory Apparatus of Inia geoffrensis and Sotalia fluviatilis: Structure and Ultrastructure
}

\author{
Aparato Respiratorio Posterior de Inia geoffrensis y Sotalia fluviatilis: Estructura y Ultraestructura
}

\author{
Luzivaldo Castro dos Santos Júnior'; Miriam Marmontel²; Francisco Glauco de Araújo Santos; \\ Rose Eli Grassi Rici ${ }^{3}$; Maria Angélica Miglino ${ }^{3}$ \& Yuri Karaccas de Carvalho ${ }^{1}$
}

SANTOS JUNIOR, L.C.; MARMONTEL, M.; SANTOS, F. G.A.; RICI, R. E.; MIGLINO, M.A. \& CARVALHO, Y. K. Posterior respiratory apparatus of Inia geoffrensis and Sotalia fluviatilis: Structure and ultrastructure. Int. J. Morphol., 35(4):1582-1589, 2017

SUMMARY: This study aimed to characterize the structures of the posterior respiratory system of two species of river dolphins: Inia geoffrensis and Sotalia fluviatilis. The respiratory tract of both species was evaluated using macro and microscopic techniques. Four macroscopic anatomical structures were identified: Trachea, main bronchus, tracheal bronchus and lung. The presence of the exuberant tracheal bronchus suggested ease of gas exchanges. Histological analysis revealed the presence of alveolar ducts and myoelastic sphincter in these Amazonian cetaceans. The posterior respiratory portion of the Amazonian dolphins presents similarity with other odontocetes and the knowledge of this structure can also help contribute to the understanding of the physiology of diving and how these species are adapted to their habitat.

KEY WORDS: Amazon river dolphin; Tucuxi; Anatomy.

\section{INTRODUCTION}

Cetartiodactyla is one of the most diversified orders of mammals and includes cetaceans, animals that have acquired anatomical adaptations to adaptation aquatic life, such as a fusiform body and modified limbs (de Muizon, 2009; Uhen, 2010; Reeves et al., 2011; Hassanin et al., 2012). The Amazonian cetaceans boto Inia geoffrensis (Reeves et al.) and tucuxi Sotalia fluviatilis (Secchi, 2012) are listed as "Data Deficient" according to the International Union for the Conservation of Nature and Natural Resources.

Both botos and tucuxis are distributed in the Amazon and Orinoco River basins (Best \& da Silva, 1993; da Silva \& Best, 1996).

Studies on the biological characteristics of freshwater dolphins started when the first taxonomic study of these species was performed by Gray in 1863 (Kida, 1990). These animals possess a set of anatomical specializations that, due to evolutionary needs, improve diving capacity, including an increase in size of body and of cavities, oxygen storage
(Piscitelli, 2009). The respiratory system, which begins at the blowhole, passes through the trachea and ends in the lungs (Berta et al., 2005).

The morphological pattern of the tracheobronchial tree is similar among the different species of cetaceans, confirming the phylogenetic relationships between these animals, which can be verified in Lipotes vexillifer, Platanista sp. and Pontoporia blainvillei (Kaiya, 1982; Endo et al., 1999).

Amazonian cetaceans present conflicts with fishing, often in a negative way (Santos Junior \& Marmontel, 2016). This inter-specific interaction between fishermen and cetaceans may lead to death (Parsons \& Jefferson, 2000).

This work aimed to characterize the posterior respiratory apparatus of Inia geoffrensis and Sotalia fluviatilis, from macroscopic and microscopic analysis of the trachea, bronchi and lungs.

\footnotetext{
${ }^{1}$ Postgraduate Program in Sanitary and Sustainable Animal Production in Western Amazonia, Federal University of Acre, University Campus - BR 364, km 4 - Industrial District, Rio Branco, AC, Brazil.

${ }^{2}$ Research Group on Amazonian Aquatic Mammals, Mamirauá Institute for Sustainable Development - Estrada do Bexiga, 2584, Tefé, AM, Brazil.

${ }^{3}$ School of Veterinary Medicine and Zootechnics, University of São Paulo - Av. Prof. Dr. Orlando Marques de Paiva, 87 - Cidade Universitária, São Paulo, SP, Brazil.
} 


\section{MATERIAL AND METHOD}

Carcasses of Amazon river dolphins were collected in Lake Tefé and the Mamirauá and Amanã sustainable development reserves (Fig. 1), located in the region of mid Solimões river, near the town of Tefé, Amazonas, Brazil. These carcasses were collected between 1995 and 2015 and underwent a process of biometry and necropsy.

The research was approved by the Federal University of Acre (UFAC) Committee on Ethics in the Use of Animals (protocol number 05/2017) and registered in the Biodiversity Information and Authorization System (IBAMA) under the numbers 44557-1/2014 and 44577-2/2015.

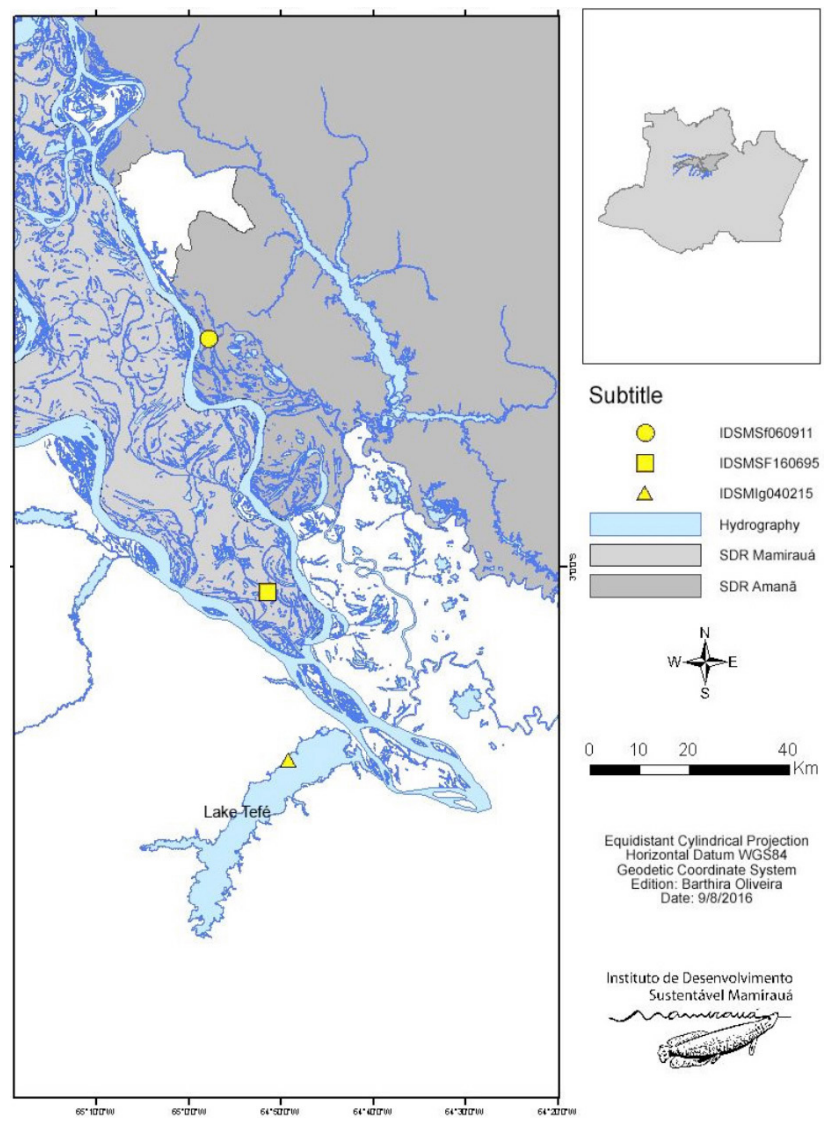

Fig. 1. Study area and collection points of carcasses.
Samples of the posterior respiratory system (Table I) were preserved in $10 \%$ formaldehyde solution in the Aquatic Mammals Laboratory of the Mamirauá Institute for Sustainable Development (MISD).

The structures that make up the posterior respiratory system of boto and tucuxi were evaluated macroscopically at the UFAC's Laboratory of Animal Anatomy (Center for Biological and Nature Sciences) and the following biometric parameters were taken: length, width and thickness of the components of the trachea, tracheal bronchus, main bronchi and lungs. For the nomenclature of the structures and their components, the Nomina Anatomica Veterinaria was used (ICVGAN, 2012).

After the macroscopic analysis, fragments of the trachea, tracheal bronchus, main and secondary bronchi, and lungs were removed from the parietal and mediastinal surfaces in their cranial, middle and caudal regions. Optical microscopy was performed at the MISD's Histology Laboratory. Samples were submitted to conventional histological processing with five-micrometer sections on a Slee Cut $5062^{\circledR}$ microtome. For each fragment, slides were prepared with the selection of five non-serial sections each, which were stained in Harris Hematoxylin and Eosin (HE). The slides thus processed were observed and photodocumented in distinct fields on the Motic BA $410^{\circledast}$ microscope with coupled camera.

Scanning Electron Microscopy was performed at the Advanced Center for Diagnostic Imaging (CADI) of the School of Veterinary Medicine and Animal Science of the University of São Paulo (CF-FMVZ/USP). We collected $1.0 \mathrm{~cm}$-long fragments of the cranial and caudal portions of the trachea, tracheal bronchus, main bronchi and lungs, washed in distilled water for $20 \mathrm{~min}$ and post-fixed in $1 \%$ osmium tetroxide solution (Polyscience ${ }^{\circledR}$, Inc. USA) for 2 hours. The fragments were dehydrated in ascending series of ethanol (50\% to $100 \%)$ for $30 \mathrm{~min}$ each. Dehydration to the critical point of $\mathrm{CO}_{2}$ occurred in Balzers ${ }^{\circledR} \mathrm{CPD} 020$ (FMVZ/USP). The samples were mounted on metallic bases (stub) using carbon glue and metallized with gold in the EMITECH ${ }^{\circledast}$ K550 (FMVZ-USP) apparatus, analyzed and photographed using a scanning electron microscope (Morgagni 268D - Phillips ${ }^{\circledR}$ ).

Table I - Data of the river dolphins used in this study.

\begin{tabular}{lcccl}
\multicolumn{1}{c}{ Species } & Code & Length $(\mathbf{c m})$ & Age class & Collected materials \\
\hline S.fluviatilis & IDSMSf160695 & 82 & Calf & Trachea, bronchi, right and left lungs \\
S. fluviatilis & IDSMSf060911 & 148 & Adult & Right and left lungs \\
I. geoffrensis & IDSMIg040215 & 213 & Adult & Trachea, bronchi, right and left lungs \\
\hline
\end{tabular}




\section{RESULTS AND DISCUSSION}

Macroscopic Analysis. The conductive portion of the boto and tucuxi respiratory tract consists of the trachea, tracheal bronchus, right and left main bronchi and secondary bronchi, all of which have incomplete cartilaginous rings with a rounded shape (Fig. 2). In other species (e.g. Tursiops truncatus, Grampus griseus and Stenella coeruleoalba), this structure of the tracheal apparatus indicated an increase in its resistance and rigidity, mainly to withstand water pressure (Bagnoli et al., 2011).

The trachea is a tube that begins in the larynx and ends in the tracheal bifurcation of the main bronchi. The trachea of the boto and tucuxi is conical and wide, similar to those found in other odontocetes, as Platanista gangetica and Pontoporia blainvillei (Kida) and Lagenorhynchus acutus (Moore et al., 2014).

These results are similar to those found in the study by Henry et al. (1983), which shows that tracheal rings of many cetaceans vary in their cartilages in different regions of the organ, these being generally dorsally open (Smodlaka et al., 2009). In our findings, both in the cranial, middle and caudal regions, the cartilages were dorsally open. These cartilages have the function of coating the flat $\mathrm{C}$-shaped rings present on the tracheal wall of some aquatic mammals (Gray et al., 2006).

The trachea of the analyzed boto and tucuxis also demonstrated trabecular surface pattern, a result compatible with Reidenberg \& Laitman (2014), who concluded that such a tracheal pattern in these animals facilitates the contraction of volume, since this portion of the tracheal wall is flexible. Unlike the mysticete cetaceans, the boto and the tucuxi did not present a pattern of parallel tracheal folds, because these two species are considered shallow-diving animals and thus do not need to adapt to larger volume changes necessary to make deep dives (Reidenberg \& Laitman).

Both species presented spiral cartilaginous rings in both the trachea and the tracheal bronchus and main bronchi, similar to those found in Delphinus delphis and Lagenorhynchus acutus by Moore et al. (2014). These authors suggest that the spiral format of these rings is related to evolutionary issues in the different species of odontocete cetaceans, such as an adaptation to withstand pressure while diving.

The number of rings in the trachea of the boto was 16 , in the tracheal bronchus there were 24 rings and on the right and left main bronchi there were 30 and 55 rings, respectively. In the tucuxi calf the number of rings was not counted, due to impossibility of visualization.

The length of the trachea of the adult boto was $6.93 \mathrm{~cm}$, whereas in the tucuxi calf $4.41 \mathrm{~cm}$ (Table II); such lengths are compatible with the size range of these species. Moore et al. (2014), when describing an adult individual of Delphinus delphis, a marine dolphin species, claim that its trachea had length of $10 \mathrm{~cm}$. The size attributed to the boto, whether of its body and one of its anatomical structures, can be attributed to its displacement in narrow environments of the Amazonian rivers (Martin \& da Silva, 2004).
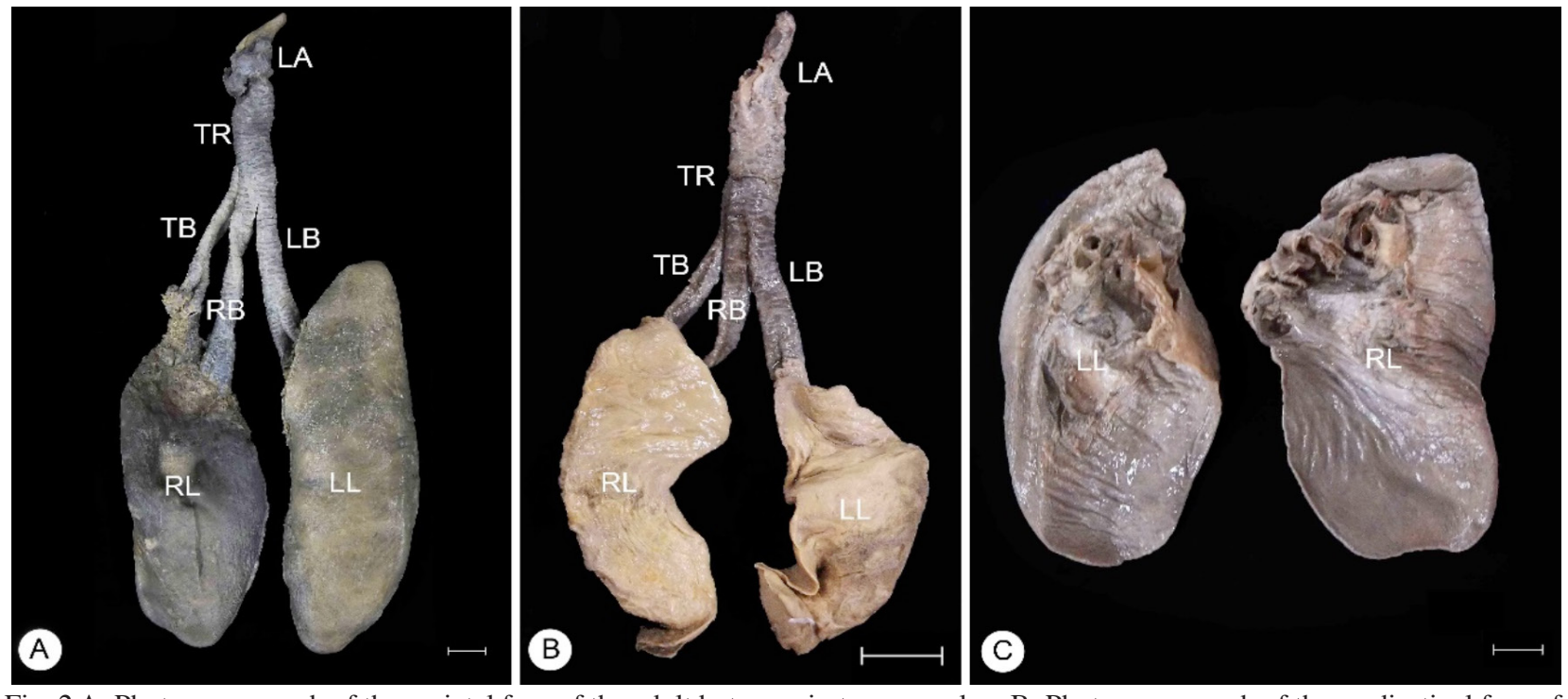

Fig. 2 A. Photomacrograph of the parietal face of the adult boto respiratory complex; B: Photomacrograph of the mediastinal face of the tucuxi calf respiratory complex; C: Photomacrograph of the mediastinal face of the adult tucuxi lung. LL-Left Lung Lobe, RL-Right Lung Lobe, LA-Larynx, LB-Left Main bronchus, RB-Right Main Bronchus, TB-Tracheal Bronchus, TR-Trachea. $\mathrm{Scale}=3 \mathrm{~cm}$. 
Table II. Morphometric measures (in centimeters) of length (L), width $(\mathrm{W})$ and height $(\mathrm{H})$ of the portions of the posterior respiratory apparatus of boto and tucuxi.

\begin{tabular}{llcccc}
\hline \multicolumn{1}{c}{ Specimen } & \multicolumn{1}{c}{ Organ } & Antimer & \multicolumn{3}{c}{ Measure } \\
& & & $\mathrm{L}$ & $\mathrm{W}$ & $\mathrm{H}$ \\
\hline Calf Tucuxi & Traquea & - & 4.41 & 2.17 & 0.86 \\
IDSMSf160695 & Tracheal bronchus & - & 5.91 & 1.34 & 0.24 \\
& & $\mathrm{R}$ & 6.09 & 0.94 & 0.35 \\
& Main bronchus & $\mathrm{L}$ & 8.67 & 1.17 & 0.26 \\
& Lung & $\mathrm{R}$ & 12.35 & 2.39 & 3.10 \\
& & $\mathrm{~L}$ & 12.72 & 2.76 & 5.93 \\
Adult boto & Traquea & - & 6.93 & 3.74 & 2.77 \\
IDSMIg040215 & Tracheal bronchus & - & 9.75 & 1.75 & 1.97 \\
& Secondary tracheal bronchus & $\mathrm{R}$ & 4.45 & 0.11 & 1.74 \\
& & $\mathrm{~L}$ & 4.07 & 0.83 & 2.05 \\
& & $\mathrm{R}$ & 10.2 & 0.53 & 1.99 \\
& Main bronchus & $\mathrm{L}$ & 12.09 & 1.40 & 1.70 \\
& & $\mathrm{R}$ & 31.60 & 10.85 & 30.3 \\
Adult tucuxi & Lung & $\mathrm{L}$ & 30.55 & 11.14 & 41.1 \\
IDSMSf060911 & Lung & $\mathrm{R}$ & 23.89 & 13.80 & 87.0 \\
& & $\mathrm{~L}$ & 27.79 & 13.92 & 77.8 \\
\hline
\end{tabular}

The tracheal bronchus of the boto and tucuxi is inserted into the apex of the right pulmonary lobe near the insertion of the main right bronchus. This tracheal bronchus is a notable feature for cetacean species, facilitating gas exchange and increasing diving time, as previously described in other river dolphins, such as Platanista gangetica (Endo et al.). The tracheal bronchus, as well as the left main bronchus, also presented two bronchial branches, inserted in the pulmonary apex.

This tracheal bronchus in boto and tucuxi corresponds to type II of the Nakakuki model, because in these Amazonian cetaceans, the bifurcation in the tracheal bronchus starts in the middle portion of the trachea when compared to other river dolphins (Nakakuki, 1980 apud Kida). The right and left lungs of the boto and tucuxi exhibit a single cylindrical shaped lobe whose length is greater than its width. These findings are in line with those described by Piscitelli et al. (2013) in marine cetaceans.

Microscopic Analysis. The tracheas of both species presented incomplete rings (Fig. 3A) and this characteristic supports the idea that the rings become less rigid. However, union with other rings forms an apparently firmer structure, aiding in compression under pressure (Moore et al., 2014).

Microscopically the trachea presented hyaline cartilage composed of chondrocytes (Fig. 3B) and was covered by a fibrous adventitial tunica composed of collagen fibers, blood vessels and adipose tissue.
The trachea, as well as the tracheal bronchi and main bronchi of boto and tucuxi, presented elastic fibers in its fibrous adventitial tunica (Fig. 3B). These are related to the depth of the dive, which was reported by Moore et al. (2011) on deep divers. However, for the boto and tucuxi the presence of elastic fibers likely guarantees higher ventilatory rates, since they live in limnetic regions (shallow regions).

Cetacean lung size has been described in several ways, including total lung mass, total lung volume and a variety of air storage capacity measurements (Piscitelli et al., 2010). The lungs have no lobes and the main bronchus is gradually reduced in its caudal and branched region in successive segmental bronchi (Piscitelli).

The pulmonary pleura (Fig. 4B) of the boto and tucuxi has a lining function, and is formed by a broad serous layer of pseudo-stratified epithelium containing smooth muscle, elastic fibers, and blood vessels, which are present in greater quantity in deep divers (Piscitelli et al., 2013). This thick pleura in aquatic mammals is suggested to confer rigidity to the lung, giving it greater resistance to compression during diving (Gray et al.). There is also a layer of collagen fibers and fibroblasts, besides the smooth muscle that appears in the alveolar opening, forming the alveolar wall.

The lungs of both species have alveolar sacs composed of simple pulmonary alveoli, formed by connective tissue and small blood vessels (Fig. 4A). The alveolar walls have dense alveolar septa composed of connective tissue at their ends (Fig. 4B). It is believed that these septa serve for 


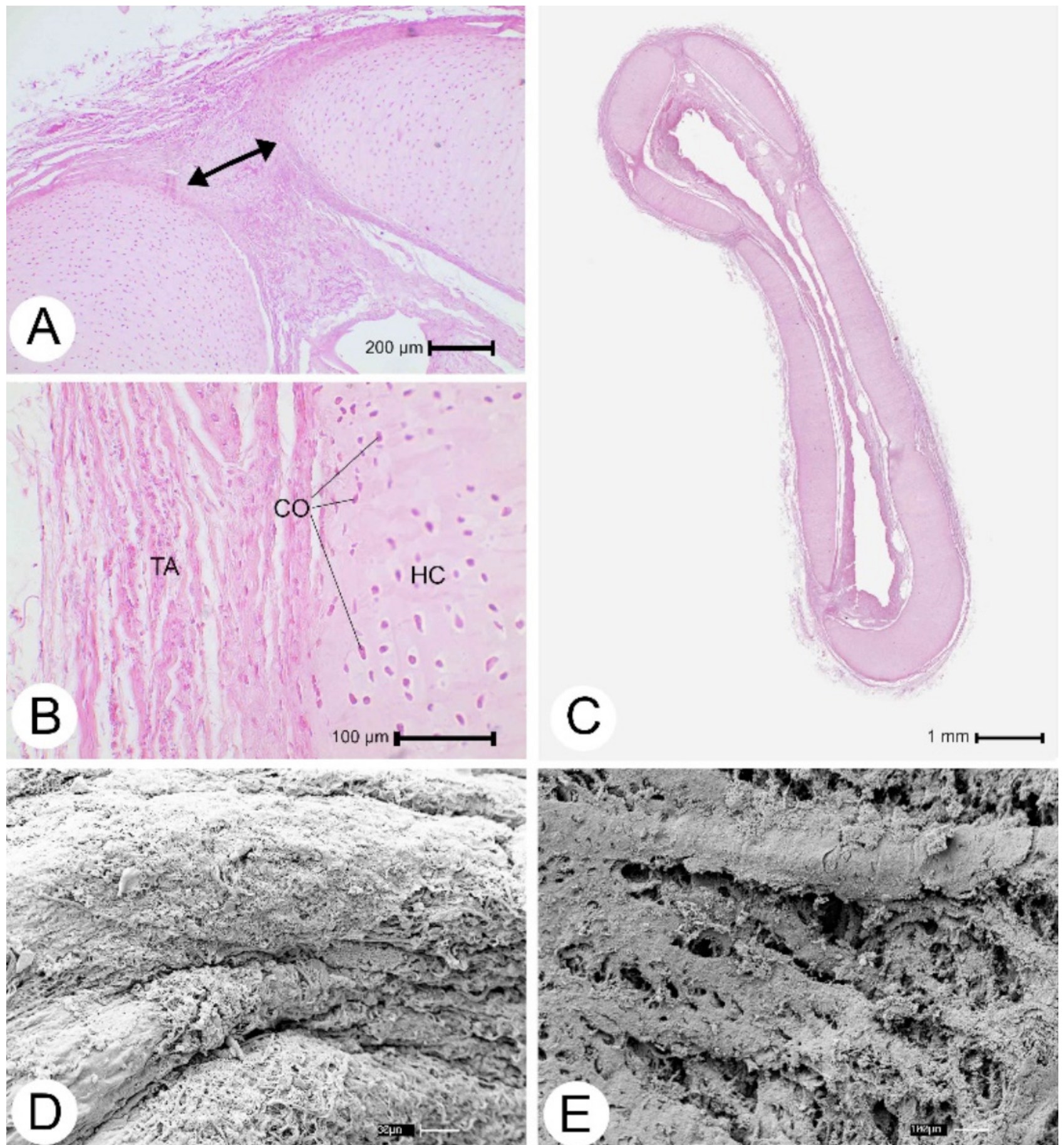

Fig. 3 A: Photomicrograph of part of the tracheal bronchus of the tucuxi calf, with spacing between the rings (arrow) (HE); B: Photomicrograph of trachea with elastic fibers of tucuxi calf (HE); C: Tracheal bronchus photomicrograph of tucuxi calf (HE); D: Photomicrograph of fibrous tunic of the tucuxi calf (MEV); E: Visceral pulmonary pleura photomicrograph of adult boto (MEV). HC-hyaline cartilage, TA- Tunica adventitia fibrosa, CO-chondrocytes.

oxygen storage, as described by Shimokawa et al. (2011). Although Yamasaki et al. (1977) did not mention the existence of alveolar ducts in Platanista sp. (Piscitelli et al., 2013), the alveolar ducts appear clearly in the lungs of river dolphins the present study.
The respiratory bronchioles (Fig. 4C) of the boto and tucuxi are shaped like irregular rings and isolated parts, surrounded by hyaline cartilage. The bronchiole has its layer formed by serous tunic, with small amount of smooth muscle fibers. Yamasaki et al. identified smooth muscles 

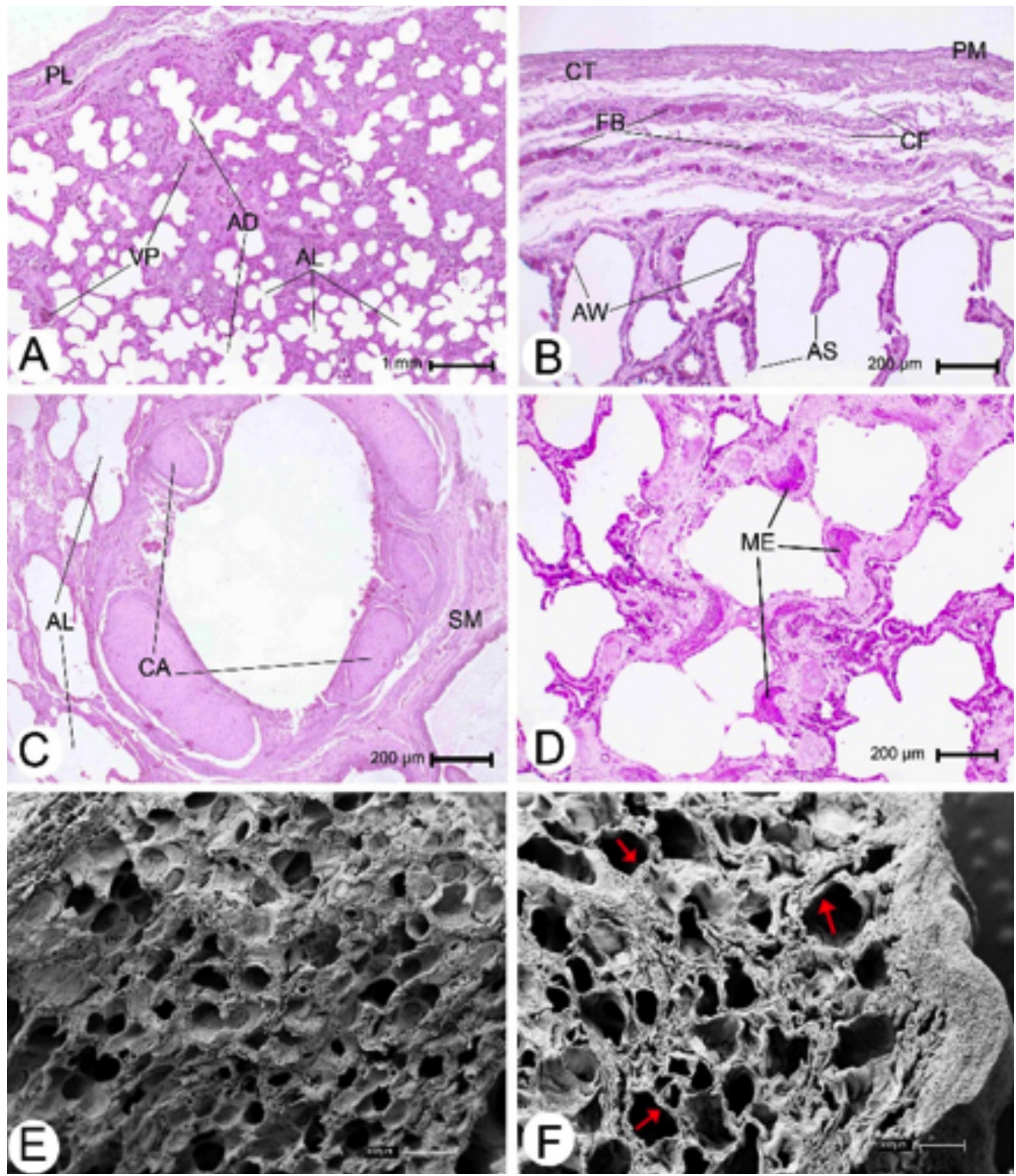

Fig. 4. A. Adult tucuxi left lung photomicrograph (HE); B: Photomicrograph of the detail of adult tucuxi (HE) left lung; C: Adult bronchodilator (HE) photomicrograph; D: Photomicrograph of detail of the presence of myoelastic sphincters in the adult tucuxi lung (HE); E: Photomicrograph of adult tucuxi alveolar sacs (SEM); F: Photomicrograph of the alveolar walls of adult boto alveolar sacs (arrow) (SEM). AS- Alveolar septum, PL-Pulmonary pleura, PM- Pleural mesothelium, CT- Pleural connective tissue, ME- Myoelastic sphincter, FB- Fibroblasts, CF- Collagen fibers, AW- Alveolar wall, AL- Alveolar sacs, PV- pulmonary vessels, AD-alveolar ducts, CA-cartilage, SM-submucosa. 
well developed in bronchioles in the lungs of Pontoporia blainvillei and Gray et al . describe a large number of smooth muscle fibers in the wall of the respiratory bronchioles in the leopard seal Leptonychotes weddellii, attributed by the authors to the species' need to reach great depths of diving. However, these characteristics are not present in boto and tucuxi, which are species of shallow dives and do not require large fibers of elastic fibers to perform their functions.

Although Yamasaki et al . did not describe the presence of myeloelastic sphincters in the river dolphins lungs, our findings demonstrated that myoelastic sphincters (Fig. 4D) can be found in the proximities of the alveolar sacs of the two species of Amazonian cetaceans, a fact that resembles the study of Crespo \& Lauria De Cidre (2005), who showed the presence of myoelastic sphincter distributed near the alveolar sacs of the lungs of Pontoporia blainvillei. It is clear that these sphincters are more developed in species of deep diving, having the function of regulating the air flow during the dive. However, in shallow divers, these sphincters are less developed and may be associated with the absence of alveolar collapses, that is, retraction of some or all of the alveoli (Crespo \& Lauria De Cidre).

\section{CONCLUSION}

Our findings indicate that the respiratory apparatus of Amazonian river dolphins is similar to other groups of aquatic mammals, including other cetaceans. Boto and tucuxis present tracheal bronchi, which is the main characteristic that differs from the lower respiratory system of these river dolphins with several species of terrestrial mammals such as man or dog, that do not have this structure. In addition, the knowledge of this apparatus helps in understanding the physiology of diving and suggests the adaptation of the species to their habitat.

SANTOS JUNIOR, L. C.; MARMONTEL, M.; SANTOS, F. G. A.; RICI, R. E.; MIGLINO, M. A. \& CARVALHO, Y. K. Aparato respiratorio posterior de Inia geoffrensis y Sotalia fluviatilis: Estructura y ultraestructura. Int. J. Morphol., 35(4):15821589, 2017.

RESUMEN: Este estudio tuvo como objetivo caracterizar las estructuras del flujo respiratorio de dos especies de delfines de agua dulce: Inia geoffrensis y Sotalia fluviatilis. Los tractos respiratorios fueron estudiados con las técnicas de evaluación macroscópica y microscópica. En ambas especies se identificaron cuatro estructuras anatómicas macroscópicas: tráquea, bronquios principales, bronquio traqueal y los pulmones. La presencia de un bronquio traqueal exuberante sugiere un aumento en el intercambio de gases y el aumento de tiempo de inmersión de las especies. El análisis histológico reveló la presencia de los conductos alveolares, y del esfínter mioelástico en los cetáceos amazónicos. La porción respiratoria posterior de los delfines del Amazonas tiene similitud con otras ballenas dentadas y su conocimiento puede contribuir a la comprensión de la fisiología del buceo y a como estas especies están adaptadas a su hábitat.

PALABRAS CLAVE: Delfín rosado; Delfín gris; Anatomía.

\section{ACKNOWLEDGMENTS}

We thank the Mamirauá Institute of Sustainable Development for assigning the samples used in this study; the Animal Anatomy Laboratory of the School of Veterinary Medicine and Animal Science of the University of São Paulo (Advanced Center for Diagnostic Imaging - CADI - FMVZ/ USP) for the elaboration of electron microscopy; Barthira Oliveira for the preparation of the map of the study area and Fernanda Silva for help in the processing of histological material. To the National Council for Scientific and Technological Development (CAPES) and the Foundation for Research Support of the State of Acre (FAPAC) for granting scholarship to Santos Júnior.

\section{REFERENCES}

Bagnoli, P.; Peruffo, A.; Costantino, M. L. \& Cozzi, B. The upper respiratory tract of dolphins. Ital. J. Anat. Embryol., 116(3):159-64, 2011.

Berta, A.; Sumich, J. L. \& Kovacs, K. M. Marine Mammals: Evolutionary Biology. 2nd ed. London, Academic Press, 2005.

Best, R. C. \& da Silva, V. M. F. Inia geoffrensis. Mamm. Species, (426):18, 1993.

Crespo, F. A. \& Lauria De Cidre, L. Functional significance of bronchial sphincters in two Southwestern Atlantic Dolphins: Pontoporia blainvillei and Lagenorhynchus obscurus: a comparative approach. Mammalia, 69(2):233-8, 2005.

da Silva, V. M. F. \& Best, R. C. Sotalia fluviatilis. Mamm. Species, (527):17, 1996.

de Muizon, C. L'origine et l'histoire évolutive des Cétacés. Comptes Rendus Palevol, 8(2-3):295-309, 2009.

Endo, H.; Yamagiwa, D.; Arishima, K.; Yamamoto, M.; Sasaki, M.; Hayashi, Y. \& Kamiya, T. MRI examination of trachea and bronchi in the Ganges River dolphin (Platanista gangetica). J. Vet. Med. Sci., 61(10):1137-41, 1999.

Gray, R.; Canfield, P. \& Rogers, T. Histology of selected tissues of the leopard seal and implications for functional adaptations to an aquatic lifestyle. J. Anat., 209(2):179-99, 2006.

Hassanin, A.; Delsuc, F.; Ropiquet, A.; Hammer, C.; Jansen van Vuuren, B.; Matthee, C.; Ruiz-Garcia, M.; Catzeflis, F.; Areskoug, V.; Nguyen, T. T. \& Couloux, A. Pattern and timing of diversification of Cetartiodactyla (Mammalia, Laurasiatheria), as revealed by a comprehensive analysis of mitochondrial genomes. C. R. Biol., 335(1):32-50, 2012. 
Henry, R. W.; Haldiman, J. T.; Albert, T. F.; Henk, W. G.; Abdelbaki, Y. Z. \& Duffield, D. W. Gross anatomy of the respiratory system of the bowhead whale, Balaena mysticetus. Anat. Rec., 207(3):435-49, 1983.

International Committee on Veterinary Gross Anatomical Nomenclature (ICVGAN). Nomina Anatomica Veterinaria. $15^{\text {th }} \mathrm{ed}$. Sapporo, Editorial Committee, 2012.

Kaiya, Z. Classification and phylogeny of the Superfamily Platanistoidea, with notes on evidence of the monophyly of the Cetacea. Sci. Rep. Whales Res. Inst., (34):93-108, 1982.

Kida, M. Y. Morphology of the tracheobronchial tree of the Ganges river dolphin (Platanista gangetica). Okajimas Folia Anat. Jpn., 67(4):28996, 1990.

Martin, A. R. \& da Silva, V. M. F. River dolphins and flooded forest: seasonal habitat use and sexual segregation of botos (Inia geoffrensis) in an extreme cetacean environment. J. Zool., 263(3):295-305, 2004.

Moore, C.; Fahlman,A.; Moore, M.; Niemeyer, M.; Lentell, B.; Oakes, S. \& Trumble, S. Histological Investigation of the 'Slip' in Marine Mammal Tracheas. In: Society for Marine Mammalogy. The Biology of Marine Mammals. Tampa, $19^{\text {th }}$ Biennial Conference on the Biology of Marine Mammals, 2011.pp.210.

Moore, C.; Moore, M.; Trumble, S.; Niemeyer, M.; Lentell, B.; McLellan, W.; Costidis, A. \& Fahlman, A. A comparative analysis of marine mammal tracheas. J. Exp. Biol., 217(7):1154-66, 2014.

Parsons, E. C. \& Jefferson, T. A. Post-mortem investigations on stranded dolphins and porpoises from Hong Kong waters. J. Wildl. Dis., 36(2):342-56, 2000.

Piscitelli, M.A. Comparing Thoracic Morphology and Lung Size in Shallow (Tursiops Truncatus) and Deep (Kogia spp.) Diving Cetaceans. PhD Thesis. Wilmington, University of North Carolina, 2009.

Piscitelli, M. A.; McLellan, W. A.; Rommel, S. A.; Blum, J. E.; Barco, S. G. \& Pabst, D. A. Lung size and thoracic morphology in shallow- and deep-diving cetaceans. J. Morphol., 271(6):654-73, 2010.

Piscitelli, M.A.; Raverty, S. A.; Lillie, M.A. \& Shadwick, R.E. A review of cetacean lung morphology and mechanics. J. Morphol., 274(12):142540, 2013.

Reeves, R. R.; Jefferson; T. A., Karczmarski, L.; Laidre, K.; O'Corry-Crowe, G.; Rojas-Bracho, L.; Secchi, E. R.; Slooten, E.; Smith, B. D.; Wang, J. Y. \& Zhou, K. Inia geoffrensis. The IUCN Red List of Threatened Species 2011:e.T10831A3220342, 2011.

Reidenberg, J. S. \& Laitman, J. Trachea in cetacea: the inside story (17.8). FASEB J., 28(Suppl. 1):17.8, 2014.

Santos Junior, L. C. \& Marmontel, M. A mortalidade de botos (Inia geoffrensis e Sotalia fluviatilis) na região do lago Tefé, Amazonas. South Am. J. Basic Educ. Tech. Technol., 3(1):7-8, 2016.

Secchi, E. Sotalia fluviatilis. The IUCN Red List of Threatened Species 2012:e.T190871A17583369, 2012.

Shimokawa, T.; Doihara, T.; Makara, M.; Miyawaki, K.; Nabeka, H.; Wakisaka, H.; Kobayashi, N. \& Matsuda, S. Lectin histochemistry of respiratory mucosa in the Pacific white-sided dolphin. J. Vet. Med. Sci., 73(9):1233-6, 2011.

Smodlaka, H.; Henry, R. W. \& Reed, R. B. Macroscopic anatomy of the ringed seal [Pusa (Phoca) hispida] lower respiratory system. Anat. Histol. Embryol., 38(3):177-83, 2009.

Uhen, M. D. The origin (s) of whales. Ann. Rev. Earth Planet. Sci., 38:189219,2010

Yamasaki, F.; Takahashi, K. \& Kamiya, T. Lungs of Franciscana (Pontoporia blainvillei), with special references to their external aspects, weights and bronchial ramifications. Okajimas Fol.Anat. Jpn., 53(6):337-58, 1977.

\author{
Corresponding author: \\ Yuri Karaccas de Carvalho \\ Federal University of Acre \\ University Campus - BR 364 \\ km 4 -Industrial District \\ CEP: $69.920-900$ \\ Rio Branco, AC. \\ BRAZIL
}

\section{E-mail: ykaracas@yahoo.com.br}

Received: 03-05-2017

Accepted: 11-08-2017 